Jpn. J. Oral Biol., 31 : 705-711, 1989.

\title{
ORIGINAL
}

\section{A comparative study of the localization of vasoactive intestinal peptide- and substance P-like immunoreactivities in the submandibu- lar salivary glands of mice}

\author{
Anka Letić-Gavrilovič ${ }^{*}$, Satoru Shibaike, Shuichi Fukai ${ }^{1)}$, \\ Satoru Naruse ${ }^{1)}$ and Kimio Abe \\ Department of Oral Biochemistry and ${ }^{l}$ Dental Pharmacology, \\ Fukuoka Dental College, 700, Ta, Sawara-ku, \\ Fukuoka-shi 814-01, Japan \\ *Present address: Department of Biochemistry, \\ Faculty of Stomatology, University of Belgrade, \\ 11000 Belgrade, Yugoslavia
}

[Accepted for publication: May 10, 1989]

Key words : Immunocytochemistry / VIP/substance $\mathrm{P} /$ submandibular gland/mice

Summary : The localization of vasoactive intestinal peptide (VIP)- and substance P (SP)-like immunoreactivities within the submandibular salivary glands (SMG) of Balb/c male mice at 4 to 5 weeks of age were investigated. Two immunocytochemical methods using polyclonal, monospecific antibodies, the indirect immunofluorescence and peroxidase-antiperoxidase (PAP), were used to elucidate the localization of VIP. and SP-like immunoreactivities in the SMG.

Both VIP- and SP-like immunoreactivities were positive in the SMG of Balb/c male mice at 4 to 5 weeks of age. The VIP-like immunoreactivity was found in the dense plexuses around the salivary duct and in the small scattered nerves surrounding glandular acini, and particularly in the nerve cell bodies of the submaxillary ganglion. The SP-like immunoreactivity was conspicuously abundant in the excretory ducts with a rich supply of SP-positive nerves, but also very scanty in the acinus areas close to the striated ducts and interlobular excretory ducts.

It could be conclusively observed that the localization of the VIP. and SP-like immunoreactivities were different in the submaxillary ganglion, in the nerves around blood vessels and acinus areas, but very similar in the areas of the excretory and striated duct of the SMG.

\section{Introduction}

Since von Euler and Gaddum" have first discovered a factor which they designated as substance $P(\mathrm{SP})$ present in equine brain and intestinal extracts, SP has been suggested to act as a sensory neurotransmitter with a wide range of biological effects, such as hypotensive, smooth muscle contracting and sialogenic actions $^{2}$. Subsequently, SP was reported to be present in both the central and peripheral nervous systems as characterized immunocyto. chemically ${ }^{3}$.

Since vasoactive intestinal polypeptide (VIP) was first isolated from porcine small intestine by Said and Mutt $^{4}$, VIP has also been shown to be present in both the central and peripheral nervous systems as a neuropeptide with a wide range of biological effects ${ }^{5}$.

Although several reports are recently ac- 
cumulated on the distribution of VIP- and SP. like immunoreactivities within the submandibular salivary glands (SMG) of various animals $^{6-17)}$, no information is available on the distribution of both VIP- and SP-like immunoreactivities within the SMG of mice except a report ${ }^{15)}$. The present study was, therefore, designed to determine the localization of both VIP. and SP-like immunoreactivities within the SMG of mice, using polyclonal, monospecific antibodies.

\section{Materials and Methods}

\section{Specimens}

Specimens of the SMG were collected from ten $\mathrm{Balb} / \mathrm{c}$ male mice at 4 to 5 weeks of age. Mice were obtained from Institute for Experimental Medicine, Military Academy, Belgrade, Yugoslavia. The mice were perfused with $0.4 \%$ solution of benzoquinone in $0.01 \mathrm{M}$ phosphate buffered saline (PBS, pH 7.1-7.4) for $5 \mathrm{~min}$. Immediately, they were killed by cervical dislocation and the SMG was fixed in the $0.4 \%$ benzoquinone solution for $2 \mathrm{~h}$. Subsequently, the tissue was rinsed several times in a solution containing sucrose (7 $\%$ ) and sodium azide $(0.1 \%)$ in PBS. After cryostat blocks were prepared, sections were cut at 10 to $15 \mu \mathrm{m}$, collected on poly-L-lysine (PLL)-coated slides and processed for the immunostaining.

\section{Antisera}

Antisera used were kind gifts from the Histochemical Department, RPMS, Hammersmith Hospital, London, UK. Their sources were as follows :

1. Anti-C-terminal directed antisera to the natural and synthetic porcine VIP were raised in rabbits and described in detail by Wharton et al. ${ }^{\text {) }}$.

2. Polyclonal, monospecific antisera to SP were described and used by Wharton et al. ${ }^{6}$ and Polak et al. ${ }^{18)}$.

These antisera did not cross-react with other known peptide hormones in the immunocytochemical procedures (personal communication with Prof. J.M. Polak).

Second- and third-layer antibodies were as follows: Goat anti-rabbit FITC conjugated antibodies (Zymed Lab., Inc., San Francisco, $\mathrm{CA}$ ), goat anti-rabbit $\operatorname{IgG}(\mathrm{H}+\mathrm{L})$ (Miles
Lab., Inc., Elkhart, IN) and rabbit peroxidaseantiperoxidase (PAP, Miles Lab., Inc., Elkhart, IN).

\section{Immunostaining}

The indirect immunofluorescence ${ }^{19}$ and PAP $^{20}$ immunostaining methods were used. The color was visualized by $3,3^{\prime}$-diaminobenzidine tetrahydrochloride (DAB) ${ }^{21}$. After developing, the sections were counterstained with methylgreen, mounted in $80 \% \mathrm{glycol} /$ PBS and examined by an Olympus AH-2microscope. Comparative photographs were taken using Kodak Ectachrome 50 film (50 ASA).

\section{Controls}

Negative controls were as follows:

a. The tissue sections were directly incubated with each antiserum without any following antibody steps.

b. The first- or second-layer was omitted, or the first-layer was replaced with normal goat sera.

c. Antisera pre-absorbed with their respective peptides $(0.1-10 \mathrm{nmol} / \mathrm{m} l$ of diluted antiserum) were applied.

\section{Results}

Nerve fibers containing VIP- and SP-like immunoreactivities were observed in the SMG of Balb/c male mice at 4 to 5 weeks of

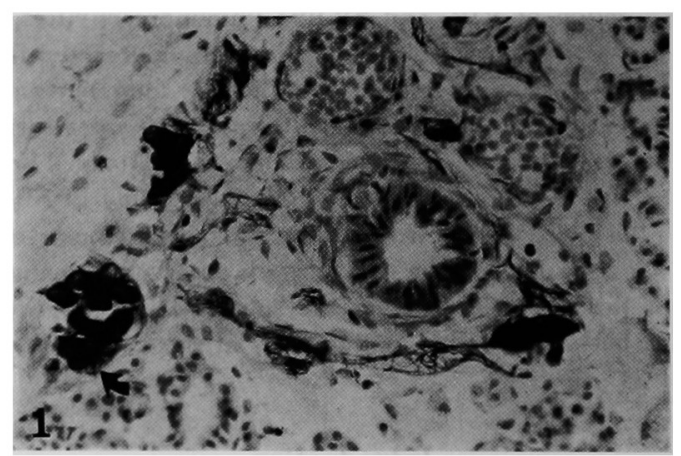

Fig. 1 The VIP-like immunoreactivity in the SMG of mice.

In the SMG of Balb/c male mice, the VIP-like immunoreactivity was detected in ganglion cell bodies and nerve fibers around the excretory duct and big blood vessels by the PAP method. Arrow denotes VIP-like immunoreactive nerve cell bodies of the submaxillary ganglion. Magnification $=\times 100$ 

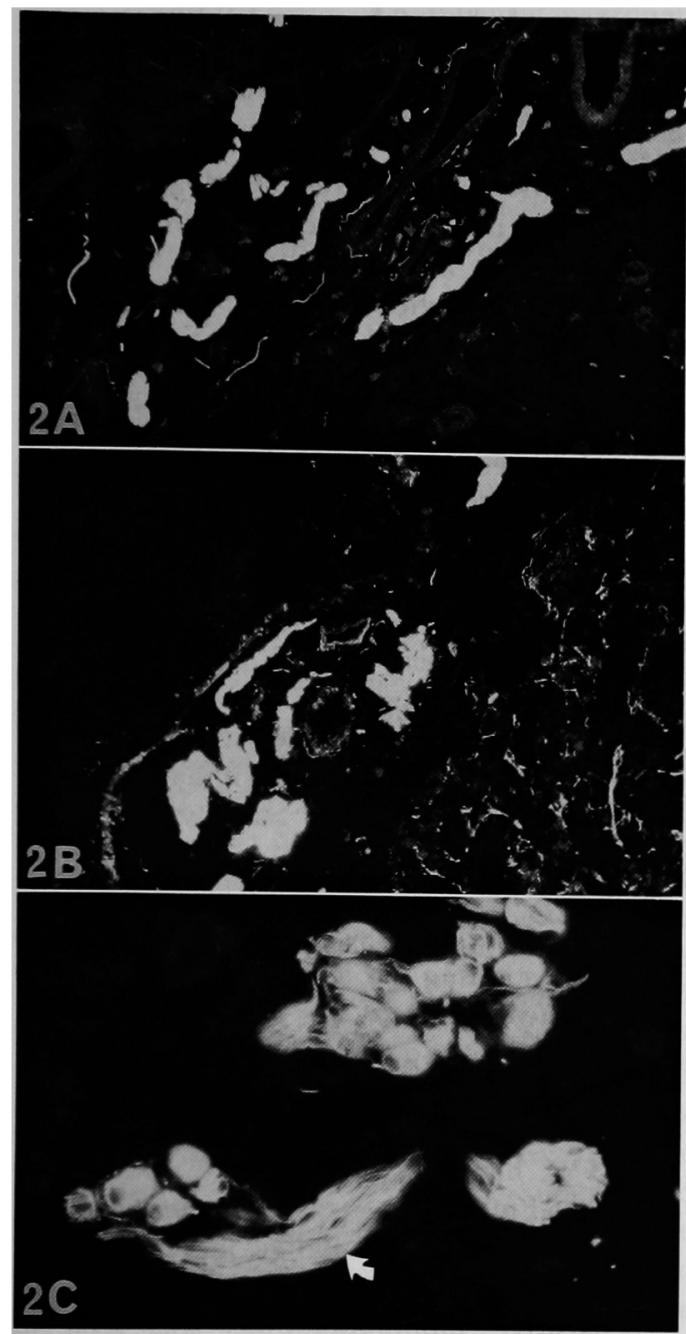

Fig. 2 The VIP-like immunoreactivity in the SMG of mice.

In the SMG of Balb/c male mice, dense plexuses of nerves rich in the VIP-like immunoreactivities (Fig. $2 \mathrm{~A}$ ), small scattered nerves around the acini (Fig. 2B) and the strong immunostaining of the nerve cell bodies of the submaxillary ganglion (Fig. 2C) were observed by the indirect immunofluorescence method. Arrow in Fig. $2 \mathrm{C}$ denotes VIP-like immunoreactive ganglion nerve cell bodies. Magnification $=\times 100$.

age. Two staining protocols, such as the PAP and indirect immunofluorescence methods, provided good results. In addition, successful quenching of the immunostaining was obtained by prior absorption of each anti-

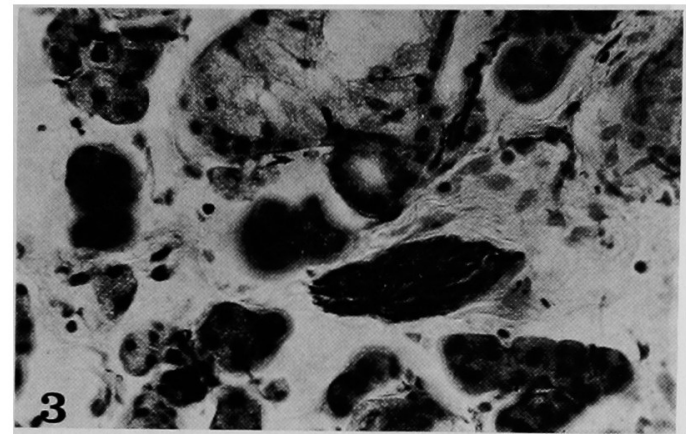

Fig. 3 The SP-like immunoreactivity in the SMG of mice.

In the SMG of Balb/c male mice, the excretory duct received a rich supply of the SP-like immunoreactivity, was observed by the PAP method. Magnification $=\times 100$.

serum with its respective antigen, such as 0.1 $\mathrm{nmol} / \mathrm{ml}$ of synthetic VIP (Sigma, V3628) or $2 \mathrm{nmol} / \mathrm{ml}$ of synthetic SP (Sigma, E8254).

VIP-like immunoreactivities were detected both in the dense plexuses of nerves around the excretory duct (Fig. 1, and Figs. 2A and $B$ ), and in the small scattered nerves surrounding the glandular acini and running to the small blood vessels (Fig. 2B). The most peculiar findings were strong VIP-like immunoreactivities in the nerve cell bodies of the submaxillary ganglion (Fig. 2C). This was obvious also after the the PAP immunostaining (Fig. 1, arrow). A bunch of thin VIP. like immunoreactive nerves originated from this ganglion nerve cell body was observed (Fig. 2C, arrow). All controls were negative.

The excretory ducts received a particularly rich supply of SP-like immunoreactive nerves, highly obvious with the PAP immunostaining (Fig. 3), but also with the indirect immunofluorescence staining (Figs. 4A and B). The distribution of SP-like immunoreactivities within the SMG was markedly patchy in the areas surrounded by nerves (Figs. $4 \mathrm{~A}$ and B). This was particularly conspicuous within the acinus areas close to the striated ducts (Fig. 4B) and interlobular excretory ducts (Fig. 4A). However, acinus areas do not lack SP-like immunoreactive nerves (Fig. 4 C). Contrary to the VIP-like immunoreactivities, the submaxillary ganglion nerve cell bodies, tiny nerves within the gland and 

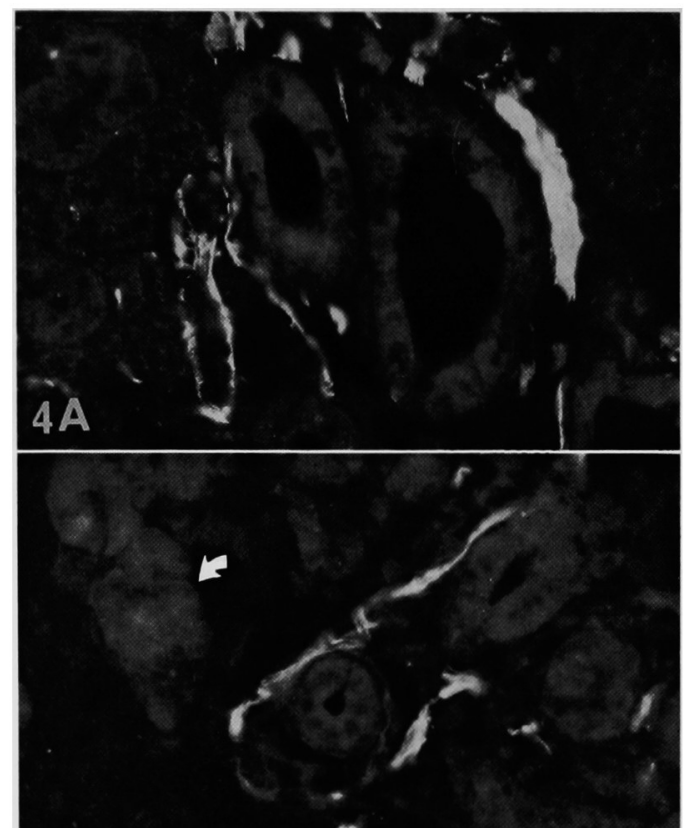

4 B

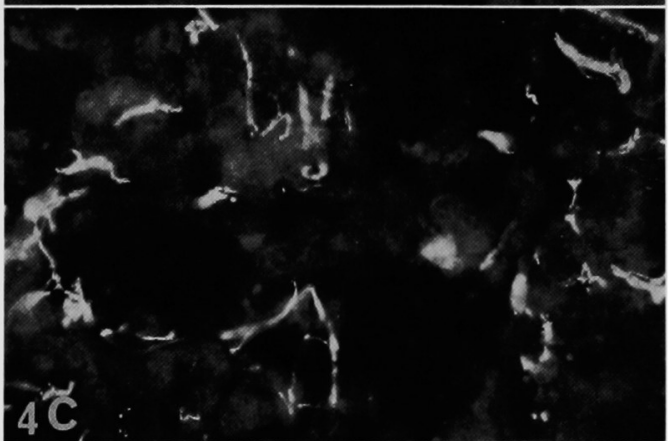

Fig. 4 The SP-like immunoreactivity in the SMG of mice.

In the SMG of Balb/c male mice, the patchy distribution of the SP-like immunoreactivity (Figs. 4A and B), and strong SP-like immunoreactive nerves close to the interlobular excretory (Fig. 4A) and striated ducts (Fig. 4B), but the distant area totally devoid of the immunoreactivity (Fig. $4 \mathrm{~B}$, arrow) can be seen. Acinus areas are innervated with SP. like nerves (Fig. 4 C). The indirect immunofluorescence method was used. Arrow in Fig. $4 \mathrm{~B}$ denotes lack of SP. like immunoreactivities in the acinus areas. Magnification $=\times 100$ blood vessels do not show any SP-like immunoreactivity. All controls were not positive.

\section{Discussion}

The existence of nerves histologically distinct from the classical cholinergic and ad renergic types was first postulated by $\mathrm{Taxi}^{22}$, and later established in detail by Baumgarten et al. ${ }^{23)}$. This new kind of nerve was referred to peptidergic (p-type). In the salivary gland, p-type neurosecretory granules have recently been elucidated by Kidd $e t$ al..$^{24)}$. The discovery of highly active regulatory peptides in the autonomic and sensory nerves of a wide range of peripheral organs, has dramatically changed old ideas of a bipartite autonomic nervous system ${ }^{\text {!'. The salivary }}$ glands are not exceptional, as they contain significantly high contents of such biologicallyactive peptides. The VIP-, originally isolated from small intestine by Said et al.4", and SP-like immunoreactivities were detected in the nerve fibers of the SMG of $\mathrm{Balb} / \mathrm{c}$ male mice at 4 to 5 weeks of age, regardless of the two staining protocols.

For the presence of the VIP-like immunoreactivities, our data were consistent with the several reports, as described by several investigators in the SMG of rats $^{6,8,16}$, cats $^{6,8,11}$, humans ${ }^{6,8)}$ and mice ${ }^{15)}$, and in the sublingual glands of rats $^{6,9)}$ in general. However, in the SMG of Balb/c male mice at 4 to 5 weeks of age, an abundant supply of VIP-positive immunostainings was seen in the nerves around the salivary duct, between the grandular acini and along the small blood vessels, and in the nerve cell bodies of the submaxillary ganglion, but not within the cells of duct or acinus portions. There are small differences of the intensity of VIP. like immunoreactivities in the salivary glands among different animal species ${ }^{6,81}$. These results on the distribution of VIP-like immunoreactivities in the SMG were also very similar to those in the human and rat pancreas ${ }^{25}$.

The origins of VIP-containing nerves in the SMG are not so far clear, but it could be postulated that they derived principally from an intrinsic neuronal system ${ }^{6,9}$, which is still unknown definitely, and in a lesser degree from the postganglionic parasympa- 
thetic nerves ${ }^{6,9,16,26)}$. An intrinsic neuronal system of VIP-containing nerve fibers should be checked by further studies in detail. A similar intrinsic system has also been postulated in SP-containing nerve fibers of the SMG of rats by Goedert et al. ${ }^{12}$. However, VIP. like immunoreactivities, as well as SP-like immunoreactivities, are also found in neurons of sensory ganglia or in the dorsal horn of the spinal cord $^{27}$.

For the presence of the SP-like immunoreactivities in the salivary glands, there are some reports on the distribution in the SMG of rats $^{7,10,12,17)}$, in the parotid glands of rats ${ }^{14)}$, dogs and mice ${ }^{10}$, and in the sublingual glands of rats $^{13,17)}$. Although all organs, in which effects of SP had been shown, also contained the SP-like immunoreactivities, as demonstrated by the immunocytochemical or radioimmunoassayable methods ${ }^{10}$, the parotid and the pooled SMG and major sublingual glands contained the highest levels of the SP. like substances among all tested organs of rats $^{10}$. No report on the distribution of the SP-like immunostaining is available in the SMG of mice. However, present results could confirm the presence of the SP-like immunostaining in the SMG of mice (Figs. 3 and 4). In the SMG of mice, the patchy and varicose SP-like immunoreactivities were observed around the excretory and striated ducts and between the acini, although the SP-like immunoreactivities were not found around the blood vessels and within the nerve cell bodies of the submaxillary ganglion. Our results were consistent with those obtained in the SMG of rats $^{12,13}$.

The dual origins of the SP-positive nerve fibers are postulated in the SMG of rats $^{12}$. One type of the SP-like immunoreactivities in the SMG of rats originates from the intrinsic system and locates around the acini, as reported on the VIP-like immunoreactivities $^{6,9)}$, whereas another type of them originates from the sensory neurons and locates mainly around the major ducts of the SMG, which is affected by neonatal capsaicin treatment, as confirmed in the heart ${ }^{28)}$, the iris $^{29)}$, the tongue ${ }^{30}$ and the dental pulp ${ }^{31}$. It is very worthwhile to know that non-capsaicin sensitive nerves containing the SP-like im. munoreactivities are predominantly present in the SMG of rats ${ }^{12}$, in contrast that VIP-like immunoreactivities are mainly present in postganglionic parasympathetic nerve fibers and coexist with acetylcholine ${ }^{15,26}$.

On the other hand, both endocrine-like and exocrine cells contain the SP-like immunoreactivities resistant to capsaicin treatment, as confirmed in the gastrointestinal tract ${ }^{32}$ and $\mathrm{SMG}^{12}$. Since the physiological roles and their origins of the intrinsic SP as well as the intrinsic VIP are yet unclear, further studies are, therefore, necessary to elucidate them definitely. The correlation between SP- and VIP-like immunoreactivities has already been examined in the dental pulp by double immunofluorescence ${ }^{33}$ and the different distribution profiles of VIP- and SP-positive nerve fibers were observed in the same blood vessels within the same sections of the dental pulp $^{33}$. In order to elucidate the co-existence of VIP- and SP-like immunoreactivities in the SMG of mice, further studies are necessary to be carried out by using the dual immunostaining methods, since very similar results were observed between VIP- and SP. like immunoreactivities in the excretory and striated ducts, but not in the submaxillary ganglion, blood vessels and acinus portions of the SMG of mice.

To elucidate the physiological roles of these neurotransmitters or neuromodalities was not our aim in this paper, but it may appear that these peptides exert various actions which could be synergistic or antagonistic, as mentioned by Polak et al. ${ }^{34}$, even in the salivary glands of mice. The complexities and a wide variety of functions of the neuroendocrine system in exocrine organs should further be elucidated in their integrities in both autonomic and sensory nervous systems in the salivary glands of animals.

\section{Acknowledgements}

We are grateful to Drs. Julia M. Polak and David Springall, Department of Histochemistry, Royal Postgraduate Medical School, Hammersmith Hospital, London, England for their kindness in supplying various antisera. This work was partly supported by a Grant-in-Aid for Scientific Research in Japan (1988). 
抄録：4〜5週㱓の Balb/c 系雄マウスの頻下腺を用いて, vasoactive intestinal polypeptide (VIP) と substance P (SP) の局在を各種のポリクロナール抗体を用いた PAP 法および間接螢光抗体法から比較検索 した。VIP および SP 陽性物質はともにマウスの穎下腺に存在していた。VIP 陽性物質は導管采周囲の神経 叢, 腺房細胞を取り囲むように存在する散在性の小神経線維，血管壁に沿って走る小神経線維および頻下神 経節の神経緗胞体に認められた。神経節では特に顕著であった。

一方，SP 陽性物質は SP 陽性神経が豊富に存在していると思われる外導管部に顕著に認められたが，線条 部や小葉間導管部に近接する腺房細胞には少ししか認められなかった。VIP と SP 陽性物質の局在は線条部 や外遒管部では非常に類似していたが，頻下神経節や腺房部では異なっていた。また，血管周囲の染色性に も両者間に相違が認められた。

\section{References}

1) Von Euler, U. S. and Gaddum, J. H. : An unidentified depressor substance in certain tissue extracts. J. Physiol. (Lond) 72:7487, 1931.

2) Leeman, S. E. and Hammerschlag, R.: Stimulation of salivary secretion by a factor extracted from hypothalamic tissue. Endocrinology 81: 803-810, 1967.

3) Hökfelt, T., Vincent, S., Dalsgaard, C-J., Skirboll, L., Johansson, O., Schultzberg, M., Lundberg, J. M., Rosell, S., Pernow, B. and Jancso, G. : Distribution of substance $P$ in brain and periphery and its possible role as a co-transmitter (Porter, R. and $\mathrm{O}^{\prime}$ Connor, M., Eds., In : Substance $\mathrm{P}$ in the nervous system), pp.84-106, Pitman, London (Ciba Foundation symposium 91), 1982.

4) Said, S. I. and Mutt, V.: Polypeptide with broad biological activity : Isolation from small intestine. Science 169 : 1217-1218, 1970.

5) Larsson, L-L., Fahrenkrug, J., Schaffalitzky de Muckadell, O. B., Sundler, F., Håkanson, R. and Rehfeld, J. F. : Localisation of vasoactive intestinal polypeptide (VIP) to central and peripheral neurons. Proc. Natl. Acad. Sci. 73 : 3197-3200, 1976

6) Wharton, J., Polak, J. M., Bryant, M. G., Van Noorden, S., Bloom, S. R. and Pearse, A. G. E.: Vasoactive intestinal polypeptide (VIP)-like immunoreactivity in salivary glands. Life Sci. 25 : 273-280, 1979.

7) Robinson, S. E., Schwartz, J. P. and Costa, E.: Substance $\mathrm{P}$ in the superior cervical ganglion and the submaxillary gland of the rat. Brain Res. $182: 11-17,1980$.

8) Uddman, R., Fahrenkrug, J., Malm, L., Alumets, J., Håkanson, R. and Sundler, F. : Neuronal VIP in salivary glands: Distribution and release. Acta Physiol. Scand. 110 : 31-38, 1980.

9) Polak, J. M, and Bloom, S. R.: Neuro- peptides in salivary glands. J. Histochem. Cytochem. $28: 871-873,1980$.

10) Brodin, E. and Nilsson, G.: Concentration of substance P-like immunoreactivity (SPLI) in tissues of dog, rat and mouse. Acta Physiol. Scand. 112 : 305-312, 1981.

11) Lundberg, J. M., Hedlund, B. and Bartfai, T.: Vasoactive intestinal polypeptide enhances muscarinic ligand binding in cat submandibular salivary gland. Nature 295 : 147-149, 1982.

12) Goedert, M., Nagy, J. I. and Emson, P. C.: The origin of substance $P$ in the rat submandibular gland and its major duct. Brain Res. 252 : 327-333, 1982.

13) Kudo, T., Inoki, R., Nishimoto, T., Akai, M., Shiosaka, S. and Tohyama, M.: A possible role of substance $\mathrm{P}$ in the salivary secretion in rats. Adv. Exp. Med. Biol. 156 A : 681-692, 1983.

14) Sharkey, K. A. and Templeton, D.: Substance $\mathrm{P}$ in the rat parotid gland: Evidence for a dual origin from the otic and trigeminal ganglia. Brain Res. 304 : 392-396, 1984.

15) Eva, C., Meek, J. L. and Costa, E. : Vasoactive intestinal peptide which coexists with acetylcholine decreases acetylcholine turnover in mouse salivary glands. J. Pharmacol. Exp. Ther. $232: 670-674,1985$.

16) Olsen, P. S., Kirkegaard, P., Poulsen, S. S. and Nex $\phi$, E.: Vasoactive intestinal polypeptide and acetylcholine stimulate exocrine secretion of epidermal growth factor from the rat submandibular gland. Regul. Peptides $15: 37-46,1986$.

17) Kamogashira, K., Yanabu, M., Ichikawa, K., Itoh, T., Matsumoto, M., Ishibashi, K. and Abe, K.: The effects of upper incisor separation on the submandibular and sublingual glands of rats. J. Dent. Res. 67: 602-610, 1988.

18) Polak, J. M. and Bloom, S. R. : Peptidergic nerves of the gastrointestinal tract. Invest. 
Cell Pathol. 1 : 301-326, 1978.

19) Coons, A. H. : Fluorescent antibody methods (Danielli, J. F., Ed., In : General Cytochemical Methods), pp.399-422, Academic Press, New York, 1958

20) Sternberger, L. A.: The unlabeled antibody peroxidase-antiperoxidase (PAP) method (Sternberger, L.A., Ed., In : Immunocytochemistry), 3rd edn., pp.90-209, John Wiley, New York, 1986.

21) Graham, R. C. Jr. and Karnovsky, M. J. : The early stages of absorption of injected horseradish peroxidase in the proximal tubules of mouse kidney : Ultrastructural cytochemistry by a new technique. J. Histochem. Cytochem. 14 : 291-302, 1966.

22) Taxi, J.: Contribution à l'étude des connections des neurons moteurs du systeme nèrveux autonome. Ann. Sci. Nat. Zool. 7 : 413-674, 1965.

23) Baumgarten, H. G., Holstein, A. F. and Owman, C.: Auerbach's plexus of mammals and man : Electron microscopic identification of three different types of neuronal processes in myenteric ganglia of the large intestine from rhesus monkeys, guinea-pigs and man. Z. Zellforsch. $106: 376-397,1970$.

24) Kidd, A. and Garrett, J. R. : New observations on the innervation of striated ducts in submandibular glands of cats, including possible peptidergic nerves. Cell Tissue Res. 200 : 205-214, 1979.

25) Bishop, A. E., Polak, J. M., Green, I. C., Bryant, M. G. and Bloom, S. R.: The location of VIP in the pancreas of man and rat. Diabetologia $18: 73-78,1980$.

26) Lundberg, J. M. : Evidence for coexistence of vasoactive intestinal polypeptide (VIP) and acetylcholine in neurons of cat exocrine glands. Morphological, biochemical and functional studies. Acta Physiol. Scand. [Suppl.] 496 : 1-57, 1981.

27) Buck, S. H., Walsh, J. H., Yamamura, H. I. and Burks, T.F.: Neuropeptides in sensory neurons. Life Sci. 30 : 1857-1866, 1982.

28) Papka, R. E., Furness, J. B., Della, N. G. and Costa, M.: Depletion by capsaicin of substance $\mathrm{P}$-immunoreactivity and acetylcholinesterase activity from nerve fibres in the guinea-pig heart. Neurosci. Lett. 27 : 47$53,1981$.

29) Miller, A., Costa, M., Furness, J. B. and Chubb, I. W. : Substance P immunoreactive sensory nerves supply the rat iris and cornea. Neurosci. Lett. 23 : 243-249, 1981.

30) Nagy, J. I., Goedert, M., Hunt, S. P. and Bond, A.: The nature of the substance P. containing nerve fibers in taste papillae of the rat tongue. Neuroscience $7: 3137-3151$, 1982.

31) Olgart, L., Hökfelt, T., Nilsson, G. and Pernow, B. : Localization of substance P. like immunoreactivity in nerves in the tooth pulp. Pain 4 : 153-159, 1977.

32) Holzer, P., Gamse, R. and Lembeck, F. : Distribution of substance $\mathrm{P}$ in the rat gastrointestinal tract-lack of effect of capsaicin pretreatment. Eur. J. Pharmacol. 61 : 303-307, 1980.

33) Wakisaka, S., Ichikawa, H., Nishikawa, S., Matsuo, S., Takano, Y. and Akai, M.: Immunohistochemical observation on the correlation between substance $P$. and vasoactive intestinal polypeptide-like immunoreactivities in the feline dental pulp. Arch. Oral Biol. 32 : 449-453, 1987.

34) Polak, J. M. and Bloom, S. R. : Peripheral localization of regulatory peptides as a clue to their function. J. Histochem. Cytochem. 28 : 918-924, 1980. 